\title{
The Application of Glyoxal-bis-(2-hydroxyanil) to the Determination of Trace Amounts of Cadmium by Spectrofluorimetry
}

\author{
Yanjie Dong* and Ke Gai \\ Chemistry and Environment College of Anqing University, 246011 Anqing City, Anhui, China
}

\begin{abstract}
A reação fluorescente do glioxal-bis-(2-hidroxianil) (GBHA) com cádmio foi estudada. A partir dessa reação quelante, um método espectrofluorimétrico direto, sensível e rápido, para determinação de traços de cádmio com GBHA, foi desenvolvido. As condições reacionais para o sistema fluorescente de cádmio com GBHA foram estabelecidas. O íon cádmio pode formar um quelato estável com GBHA, à razão de 1:3 no intervalo de pH, entre 12,0 e 13,0. Para o quelato de cádmio, os comprimentos de onda máximos de excitação e emissão são $227,4 \mathrm{~nm}$ e $320,0 \mathrm{~nm}$, respectivamente. A intensidade fluorescente do quelato de cádmio permanece estável entre 20 e $150 \mathrm{~min}$. Sob condições experimentais ótimas, a intensidade fluorescente é uma função linear da concentração de cádmio, no intervalo entre 1,0 e 10,0 ng mL $\mathrm{mL}^{-1}$ o limite de detecção é $0,65 \mathrm{ng} \mathrm{mL}^{-1}$ de cádmio. A influência de íons interferentes foi estudada. $\mathrm{O}$ método foi aplicado com sucesso na determinação de cádmio em águas de descarte.
\end{abstract}

The fluorescent reaction of the reagent glyoxal-bis-(2-hydroxyanil) (GBHA) with cadmium was studied. Based on this chelation reaction, a sensitive, rapid, direct spectrofluorimetric method for the determination of trace cadmium with GBHA has been developed. The reaction conditions for the fluorescence system of cadmium with GBHA were established. The cadmium ion can form a stable chelate with GBHA, having a ratio of 1:3 in the 12.0 -13.0 pH range. The maximum excitation and emission wavelengths are $227.4 \mathrm{~nm}$ and $320.0 \mathrm{~nm}$ for the cadmium chelate, respectively. The fluorescence intensity of the cadmium chelate remains stable from 20 to 150 min. Under the optimal experimental conditions the fluorescence intensity is a linear function of concentration in the range $1.0-10.0 \mathrm{ng} \mathrm{mL}^{-1}$ of cadmium and the detection limit is $0.65 \mathrm{ng}$ $\mathrm{mL}^{-1}$ of cadmium. Interferences of foreign ions were studied. The method has been successfully applied to the determination of cadmium in the sewage.

Keywords: glyoxal-bis-(2-hydroxyanil), cadmium, spectrofluorimetry

\section{Introduction}

The fluorescence method for the determination of rare earth element has long been recognized. ${ }^{1}$ In recent years, increasing attention has been focused on pollution of the environment. Particular attention is being paid to the heavy metals, because of their irreversible effects on health. Cadmium is one of the most important heavy metal pollutants. It and its compounds can be highly toxic to human and animals and cause serious diseases ${ }^{2}$ when it is taken in excess. It has also been noted that the environmental levels of cadmium have been slowly rising. Therefore, it is necessary to develop simple, sensitive, selective and rapid methods for its quantitative determination.

* e-mail: huaxx@ldxy.com.cn
The spectrophotometric determination of cadmium has reported very much, ${ }^{3-10}$ but these methods have a limited sensitivity. However, the fluorescence method for the determination of cadmium element has not been reported. For this reason, we have studied for the fluorescence method for the determination of cadmium. The aim of this work is to develop a rapid, sensitive, and highly selective fluorescence method for determination of cadmium. The method has been successfully applied to the determination of cadmium in the sewage.

\section{Experimental}

\section{Apparatus}

Fluorescence measurements were made on a Shimadzu RF-5000 Spectrofluorimeter equipped with a xenon light 
source and the excitation and emission slits are both 5.0 $\mathrm{nm}$. The $\mathrm{pH}$ of the solutions used was measured with a pHS-3C digital pH meter (Shanghai Leici Device Works, Shanghai, China) with a combined glass-calomel electrode. An SPECODE 50 UV spectrophotometer (analytikjena AG) equipped with $1.0 \mathrm{~cm}$ quartz cells was used for the UV spectrum scanning.

\section{Solutions}

All chemicals used were of analytical or higher grades. Deionized water was used for the preparation of all solutions. A stock standard solution of cadmium $(1.0 \mathrm{mg}$ $\mathrm{mL}^{-1}$ ) was prepared from cadmium metal and working standard solutions were prepared by dilution. A $\mathrm{NaOH}$ solution $\left(2.0 \mathrm{~mol} \mathrm{~L}^{-1}\right)$ was used. GBHA solution $(1.0 \times$ $10^{-3} \mathrm{~mol} \mathrm{~L}^{-1}$ ) was prepared by dissolving $0.2403 \mathrm{~g}$ of the reagent in $1000 \mathrm{~mL}$ of absolute ethanol. The sketch of the GBHA is showed as follows:<smiles>Oc1ccccc1N=C/C=N/c1ccccc1O</smiles>

The ultraviolet spectra of GBHA

Adding $2.0 \mathrm{~mL}$ of GBHA $\left(1.0 \times 10^{-3} \mathrm{~mol} \mathrm{~L}^{-1}\right), 0.15$ $\mathrm{mL}$ of $\mathrm{NaOH}\left(2 \mathrm{~mol} \mathrm{~L}^{-1}\right)$ and $6.0 \mathrm{~mL}$ of $100 \%$ ethanol to Erlenmeyer flask, the final volume was made up to 25 $\mathrm{mL}$ with distilled, deionized water. The ultraviolet spectra of solution of the reagent showed Figure 1.

\section{Procedure}

A standard solution of cadmium or the sample solution was placed in Erlenmeyer flask with $2.50 \mathrm{~mL}$ of GBHA

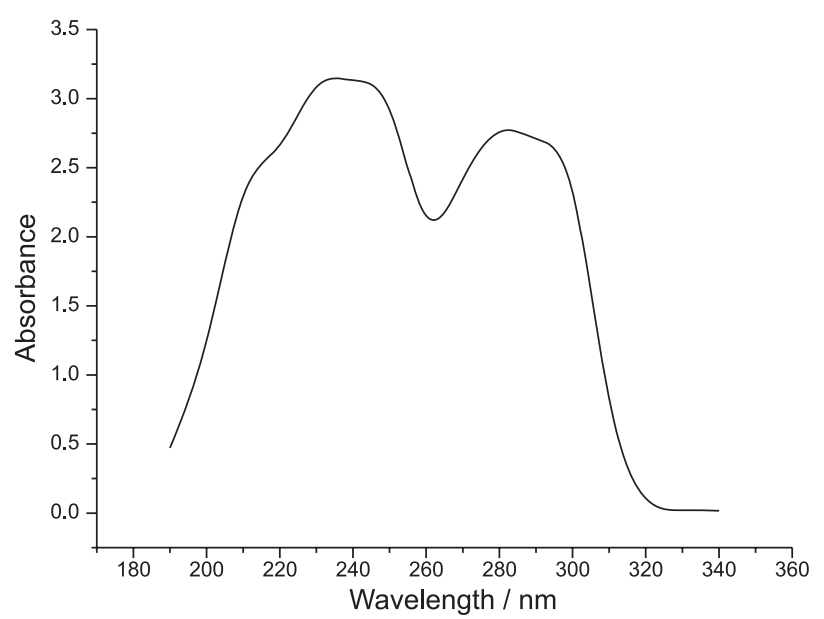

Figure 1. Ultraviolet absorption spectra of GBHA reagent; [GBHA] $=8.0$ $\times 10^{-5} \mathrm{~mol} \mathrm{~L}^{-1} ;[\mathrm{NaOH}]=0.012 \mathrm{~mol} \mathrm{~L}^{-1}$. $\left(1.0 \times 10^{-3} \mathrm{~mol} \mathrm{~L}^{-1}\right), 0.15 \mathrm{~mL} 2 \mathrm{~mol} \mathrm{~L}^{-1} \mathrm{NaOH}$ and $6.0 \mathrm{~mL}$ of $100 \%$ ethanol. The final volume was made up to 25 $\mathrm{mL}$ with distilled, deionized water. The solution was mixed and equilibrated at room temperature for $10 \mathrm{~min}$. The relative fluorescence intensity of the chelate was measured within 20 150 min at an excitation wavelength of 227.4 $\mathrm{nm}$ in a $1.0 \mathrm{~cm}$ quartz cell, keeping the emission wavelength maximum at $320.0 \mathrm{~nm}$.

\section{Results and Discussion}

\section{Excitation and emission spectra}

In order to determine the optimum working wavelength, the spectral characteristics of the Cd (II)-GBHA complex was studied. The corrected excitation and emission spectra (Figure 2) show that the wavelengths of maximum excitation and emission of the Cd(II) - GBHA complex were 227.4 $\mathrm{nm}$ and $320.0 \mathrm{~nm}$, respectively. The fluorescence intensity of reagent blank is very low.

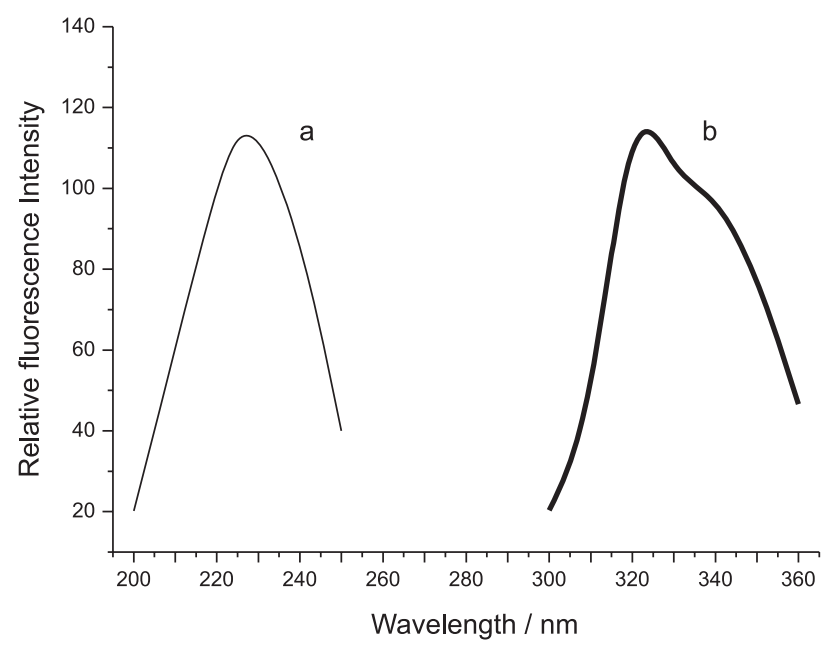

Figure 2. Excitation and emission spectra of Cd-GBHA complex. a) Excitation spectra of Cd-GBHA complex; $b$ ) emission spectra of Cd-GBHA complex; $\left[\mathrm{Cd}^{2+}\right]=5.0 \mathrm{ng} \mathrm{mL}^{-1}$, $[\mathrm{GBHA}]=1.0 \times 10^{-4} \mathrm{~mol} \mathrm{~L}^{-1},[\mathrm{NaOH}]=0.012$ mol L-1.

\section{Effect of temperature and time}

Heating can be used to speed up the attainment of the maximum fluorescence intensity, but temperature has little effect on the fluorescence intensity of the $\mathrm{Cd}(\mathrm{II})-\mathrm{GBHA}$ complex. The experimental results show that room temperature can be selected, so the experimental procedure is simple. At room temperature, the fluorescence intensity of the complex reached a maximum after $10 \mathrm{~min}$ and remained constant for at least $3 \mathrm{~h}$. 


\section{Effect of the acidity of the solution}

The variation in the fluorescence intensity at 320.0 $\mathrm{nm}$ for the cadmium chelate was investigated as a function of concentration of $\mathrm{NaOH}$. Maximum constant fluorescence intensity was obtained when $\mathrm{pH}$ of the solution was maintained between 12.0 and 13.0. Figure 3 shows that the fluorescence intensity of the cadmium chelate becomes weaker at $\mathrm{pH}<12.0$ and $\mathrm{pH}>13.0$. The reason for this is that the protonation of hydroxyl group of the chelating agent at $\mathrm{pH}<12.0$ and the intensive hydrolysis of the cadmium ion at $\mathrm{pH}>13.0$, both result in a decrease in the concentration of the chelate of cadmium with GBHA, causing a decrease in the fluorescence intensity of the cadmium chelate with GBHA.

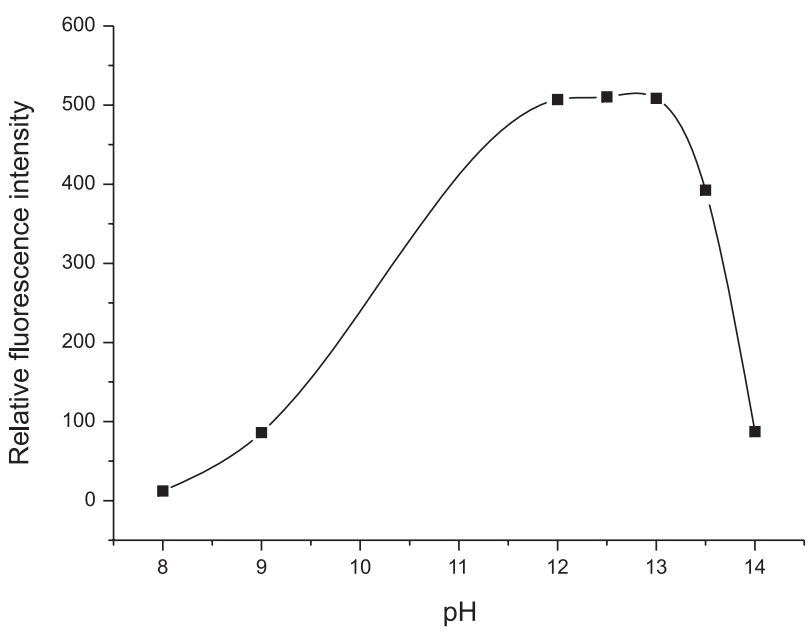

Figure 3. Effect of acidity on the fluorescence intensity of the chelate. $\left[\mathrm{Cd}^{2+}\right]=5.0 \times 10^{-5} \mathrm{~mol} \mathrm{~L}^{-1} ;[\mathrm{GBHA}]=2.0 \times 10^{-4} \mathrm{~mol} \mathrm{~L}^{-1}$.

\section{Effect of concentration of the chelating agent GBHA}

The influence of the concentration of GBHA on the fluorescent intensities of the solutions containing $3.0 \mathrm{ng}$ $\mathrm{mL}^{-1}$ of cadmium was studied under the conditions established above and Figure 4 shows the result. The fluorescent intensity increased with the increase in concentration of GBHA up to $80.0 \mu \mathrm{mol} \mathrm{L} \mathrm{L}^{-1}$, remained constant between 80.0 and $110.0 \mu \mathrm{mol} \mathrm{L^{-1 }}$. Thus $90.0 \mu \mathrm{mol}$ $\mathrm{L}^{-1}$ was selected to ensure excess of the reagent through the experimental work.

\section{Influence of amount of ethanol}

As GBHA is insoluble in water but soluble in ethanol, we studied the effect of this solvent on the fluorescent intensity of the $\mathrm{Cd}$ (II)-GBHA system. The experimental results show that the fluorescent intensity of the complex increased when the ethanol content in the medium

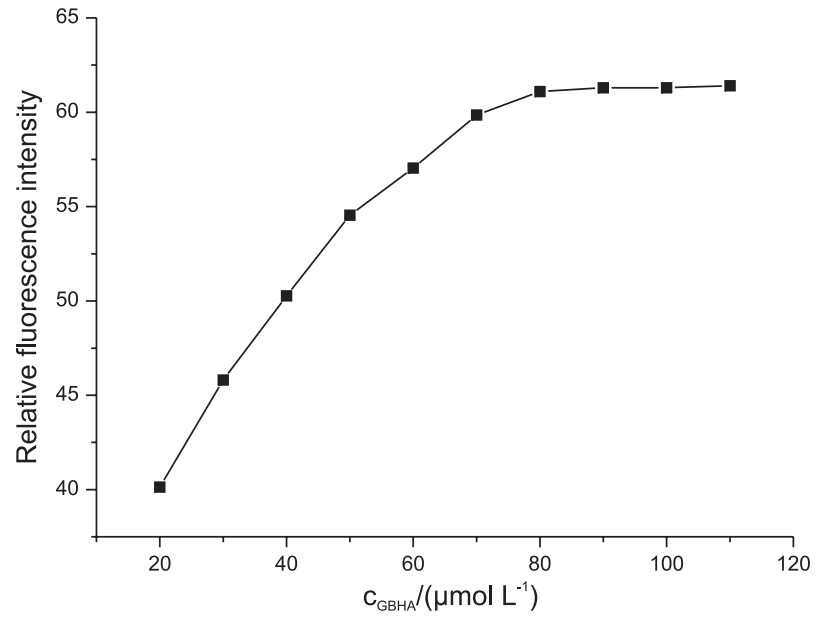

Figure 4. Effect of concentration of GBHA on the fluorescence intensity. $\left[\mathrm{Cd}^{2+}\right]=3.0 \mathrm{ng} \mathrm{mL}^{-1} ;[\mathrm{NaOH}]=0.012 \mathrm{~mol} \mathrm{~L}^{-1}$.

increased from $2.5-5.0 \mathrm{~mL}$ and remained constant between 5.0 and $7.0 \mathrm{~mL}$. Therefore, a medium containing $6.0 \mathrm{~mL}$ of ethanol in a total volume of $25 \mathrm{~mL}$ was selected.

\section{Stoichiometry of the complex}

The stoichiometry of the complex was studied under the established experimental conditions by the molar ratio and continuous variation method. ${ }^{11}$ Both methods indicated that the composition of the complex is $1: 3$.

\section{Effect of foreign ions}

A systematic study of the interferences of foreign ions in the determination of $\mathrm{Cd}^{2+}\left(5.0 \mathrm{ng} \mathrm{mL} \mathrm{m}^{-1}\right)$ was carried out. For this study, various amounts of different ions were added by firstly testing a 2000 times interference with cadmium $(\mathrm{m} / \mathrm{m})$. If interference occurred, the ratio was reduced gradually until the interference ceased. The criterion for interference was fixed at a $\pm 5 \%$ variation of the average fluorescent intensity calculated for the established level of cadmium. The results are shown in Table 1.

\section{Calibration curve}

The calibration curve for the determination of cadmium is obtained under the optimal experimental

Table 1. Effect of foreign ions on the fluorimetric determination of cadmium $\left(5.0 \mathrm{ng} \mathrm{mL}^{-1}\right)$

\begin{tabular}{ll}
\hline Tolerance ratio $(\mathrm{m} / \mathrm{m})$ & Foreign ions \\
\hline 1500 & $\mathrm{Na}^{+}, \mathrm{K}^{+}, \mathrm{NO}_{3}^{-}, \mathrm{NO}_{2}^{-}$ \\
1000 & $\mathrm{H}_{2} \mathrm{PO}_{4}^{2-}, \mathrm{Cl}^{-}, \mathrm{Br}^{-}, \mathrm{I}^{-}, \mathrm{ClO}_{4}^{-}, \mathrm{HCO}_{3}^{-}, \mathrm{SO}_{3}^{2-}, \mathrm{SO}_{4}^{2-}$ \\
500 & $\mathrm{Mg}^{2+}, \mathrm{Ca}^{2+}, \mathrm{Ba}^{2+}$ \\
200 & $\mathrm{Ni}^{2+}, \mathrm{Zn}^{2+}, \mathrm{Co}^{2+}, \mathrm{Mn}^{2+}, \mathrm{Cu}^{2+}, \mathrm{Hg}^{2+}, \mathrm{Cr}^{3+}, \mathrm{Fe}^{2+}, \mathrm{Fe}^{3+}$, \\
& $\mathrm{Sr}^{2+}, \mathrm{Al}^{3+}$ \\
\hline
\end{tabular}


Table 2. Sample analysis and recovery experiment

\begin{tabular}{cccccc}
\hline Sample & Added $\left.(\mathrm{ng} \mathrm{mL})^{-1}\right)$ & Found $\left(\mathrm{ng} \mathrm{mL}^{-1}\right)$ & Average $\left(\mathrm{ng} \mathrm{mL} \mathrm{mL}^{-1}\right)$ & Recovery $(\%)$ & RSD $(\%)$ \\
\hline 1 & 0.0 & $4.027,4.050,4.060,4.029,4.045$ & 4.042 & - & 0.14 \\
2 & 1.0 & $5.040,5.048,5.045,5.032,5.047$ & 5.042 & 100.0 & 0.67 \\
3 & 3.0 & $7.040,7.038,7.037,7.018,7.018$ & 7.032 & 99.7 & 0.05 \\
\hline
\end{tabular}

conditions. The linear range is from $1.0-10.0 \mathrm{ng} \mathrm{mL}^{-1}$. The linear equation is $\Delta \mathrm{F}=3.00 \mathrm{C}\left(\mathrm{ng} \mathrm{mL}^{-1}\right)-0.15$ (where $\Delta \mathrm{F}$ stands for difference of the fluorescence intensity of Cd(II)-GBHA complex and the fluorescence intensity of reagent blank, $\mathrm{C}$ represents the concentration of cadmium), with a linear correlation coefficient (R) 0.9988 and a standard deviation (S.D.) 0.65 . The detection limit is $0.65 \mathrm{ng} \mathrm{mL}^{-1}$ of cadmium.

\section{Sample analysis and recovery experiment}

For the assay of cadmium in sewage, $10.0 \mathrm{~mL}$ of the sewage was transferred into a crucible and heated to dryness on an electric furnace. The residue was dissolved with $1 \mathrm{~mol} \mathrm{~L}^{-1} \mathrm{HNO}_{3}$. The solution was then transferred into a $50 \mathrm{~mL}$ calibrated flask, adjusted to $\mathrm{pH} 12.5$ with dilute $\mathrm{NaOH}$ and diluted to the mark with water. Which were then determined spectrofluorimetrically by the method developed above. Experiment results are shown in Table 2. The sample was determined by chemical analyzing method, the result is $4.04 \mathrm{ng} \mathrm{mL}^{-1}$.

\section{Acknowledgments}

Natural Science Foundation of LongDong University sponsored this work.

\section{References}

1. Gao, J.; Zhao, G.; Kang, J.; Talanta 1995, 42, 1497.

2. Wang, K.; Trance Elements in Life Science, Beijing Chinese Measure Press: Beijing, 1991.

3. Akl, M. A.; Khalifa, M.E.; Ghazy, S.E.; Hassanien, M.M.; Anal. Sci. 2002, 18, 1235.

4. Saran, R.; Baishya, N.K.; Indian J. Chem., Sect. A 2001, 40A, 433.

5. Gao, H.; Tao, M.; Indian J. Chem., Sect. A 2001, 40A, 780.

6. Amin, AS.; Anal. Lett. 2001, 34, 163.

7. Chandrasekhar, K.B.; Reddy, K. H.; J. Indian Chem. Soc. 2001, 78, 340 .

8. Das, H. K.; J.Indian Chem. Soc. 2001, 78, 323.

9. Jin, G.; Kan, J.; Zhu, Y.; Lei, N.; Indian J. Chem., Sect. A 2000, 39A, 1227.

10. Al-Shawi, A.W.; Dahl, R.; Anal. Chim. Acta 1999, 391, 35.

11. Wuhan University; Analytical Chemistry, High Education Press: Beijing, 1993. 